\title{
On the influence of temporal change on the validity of landslide susceptibility maps
}

\author{
K. Meusburger and C. Alewell \\ Institute for Environmental Geosciences, University of Basel, Bernoullistrasse 30, 4056 Basel, Switzerland \\ Received: 27 February 2009 - Revised: 28 July 2009 - Accepted: 4 August 2009 - Published: 28 August 2009
}

\begin{abstract}
The consideration of non-stationary landslide causal factors in statistical landslide susceptibility assessments is still problematic. The latter may lead to erroneous model predictions, especially in times of dramatic environmental change. In this case study in the Central Swiss Alps, we aim to evaluate the effect of dynamic change of landslide causal factors on the validity of landslide susceptibility maps. Logistic regression models were produced for two points in time, 1959 and 2000. Both models could correctly classify $>70 \%$ of the independent spatial validation dataset. By subtracting the 1959 susceptibility map from the 2000 susceptibility map a deviation susceptibility map was obtained. Our interpretation was that these susceptibility deviations indicate the effect of the change of dynamic causal factors on the landslide probability. The deviation map explained $85 \%$ of new landslides occurring after 2000. We believe it to be a suitable tool to add a time element to the susceptibility map pointing to areas with changing susceptibility due to recently changing environmental conditions.
\end{abstract}

\section{Introduction}

The alpine terrain with its rugged topography and extreme climatic conditions is naturally disposed to soil erosion. Besides water erosion, mass movements are typical erosion features that constitute an important proportion to total soil loss (Meusburger and Alewell, 2008). Shallow landslides are a type of mass movement highly correlated to extreme events. Thus, unrecognised landslide causal factors can lead to hazardous surface damage and soil loss within one extreme rainfall event. The damages caused by a typical shallow translational landslide with a thickness of 0.3 to $2 \mathrm{~m}$, as defined by Tasser et al. (2003), often persist for several decades

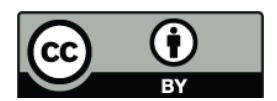

Correspondence to: K. Meusburger (katrin.meusburger@unibas.ch)
(Meusburger and Alewell, 2008) due to slow vegetation resettlement, and hampered possibilities for stabilisation measures in the alpine environment.

Landslide hazard assessment, as defined by Varnes (1984), aims at improving the knowledge of processes that lead to slope instability and, in addition, at identifying the locations where and when landslides or potentially instable slopes may occur. According to Carrara et al. (1998) approaches for landslide hazard assessment can generally be grouped into two main categories: the direct, qualitative method that relies on the ability of the investigator to estimate actual and potential slope failures and indirect, quantitative methods that produce numerical estimates (probabilities) of the occurrence of landslide in any hazard zone. The choice of the method mainly depends on the spatial scale (Van Westen, 2000) and, thus, the data availability. To assess landslide susceptibility on a regional scale, multivariate statistical approaches were commonly used in the last decades. Especially discriminant analysis (Carrara et al., 1991, 2003; Davis et al., 2006; Santacana et al., 2003), logistic regression (Ayalew and Yamagishi, 2005; Ayalew et al., 2005; Dai and Lee, 2002; Ohlmacher and Davis, 2003; Tasser et al., 2003; Van Den Eeckhaut et al., 2006; Yesilnacar and Topal, 2005) and neural networks (Ermini et al., 2005; Yesilnacar and Topal, 2005; Kanungo et al., 2006; Gomez and Kavzoglu, 2005) have successfully been applied.

Unconstrained by the statistic method chosen, the basic concept of landslide hazard assessment with statistical methods is to compare the conditions that have lead to landslides in the past with the conditions at regions currently free of landslides (Carrara et al., 1998). The assumption made when using multivariate statistics for landslide hazard prediction is that catchment characteristics leading to landslides in the past will also be susceptible to landslides in the future. This relation (between past and future) may weaken and become invalid when landslide causal factors become variable with time (called "dynamic factors" in the following) and may lead to a loss of model validity under changed

Published by Copernicus Publications on behalf of the European Geosciences Union. 
future conditions (Guzzetti et al., 1999). In view of changing climate conditions and agricultural changes the importance of the problem is increasing and validation of landslide prediction maps is essential (Chung and Fabbri, 2003; Zêzere et al., 2004).

Various studies highlight the impact of dynamic factors such as climate and land use on the probability of landslide (Frei et al., 2007; Schauer, 1975; Tasser et al., 2003; Gorsevski et al., 2006; Meusburger and Alewell, 2008). However, compared to the quantity of landslide susceptibility studies, relatively little effort has been made to validate the predictive capability of the obtained maps (Chung and Fabbri, 2003) and even less to generate maps of likely future landslide scenarios (Guzzetti et al., 2006; Irigaray et al., 2007; Zêzere et al., 2004). The latter was done for instance by integrating the susceptibility map with the return period of rainfall (Zêzere et al., 2004). The approach of return period does not account for the non-stationary behaviour of the geomorphologic system (Hufschmidt et al., 2005) and the spatially and temporally nonlinear relationship between landslides and their causative factors (Zhou et al., 2002). Hence, the spatial distribution of susceptibility zones remains unchanged and a change of the spatial susceptibility pattern over time is not considered (Zêzere et al., 2004). A strong element of uncertainty exists, when the importance of landslide causal factors changes rapidly. For instance, human action, mainly landcover- and land use changes may increase the sensitivity of the geomorphic system to the effects of precipitation and, thus, cause a shift of susceptibility zones. This negligence may impede the identification of new potential susceptibility areas and, hence, may hamper the timely initiation of prevention measures.

The aim of this study is to evaluate the impact of dynamic landslide causal factors on the validity of landslide susceptibility maps. Our hypothesis is that a temporal change of landslide causal factors cause a shift of landslide susceptibility zones. We propose an approach to extract the impact of temporal variation (changing landslide causal factors) on the probability of landslides from multi-temporal data. The subcatchment of the Urseren Valley (Central Swiss Alps) was chosen as investigation site because of its severe slope degradation by landslides and the evidence of a trend in landslide occurrence (Meusburger and Alewell, 2008).

\section{Study area and landslides}

The sub-alpine study area $\left(30 \mathrm{~km}^{2}\right.$; Fig. 1$)$ is characterised by rugged terrain with elevations ranging from $1400 \mathrm{~m}$ to $3200 \mathrm{~m}$ a.s.l. The average slope angle is approximately $27^{\circ}$. The valley is formed by the gneiss massif of the Gotthard system to the south and the granite massif and the preexisting basement (named "Altkristallin", Labhart, 1999) of the Aare system in the north. Intermediate vertically dipping layers consist of Permocarbonic and Mesozoic sedi-

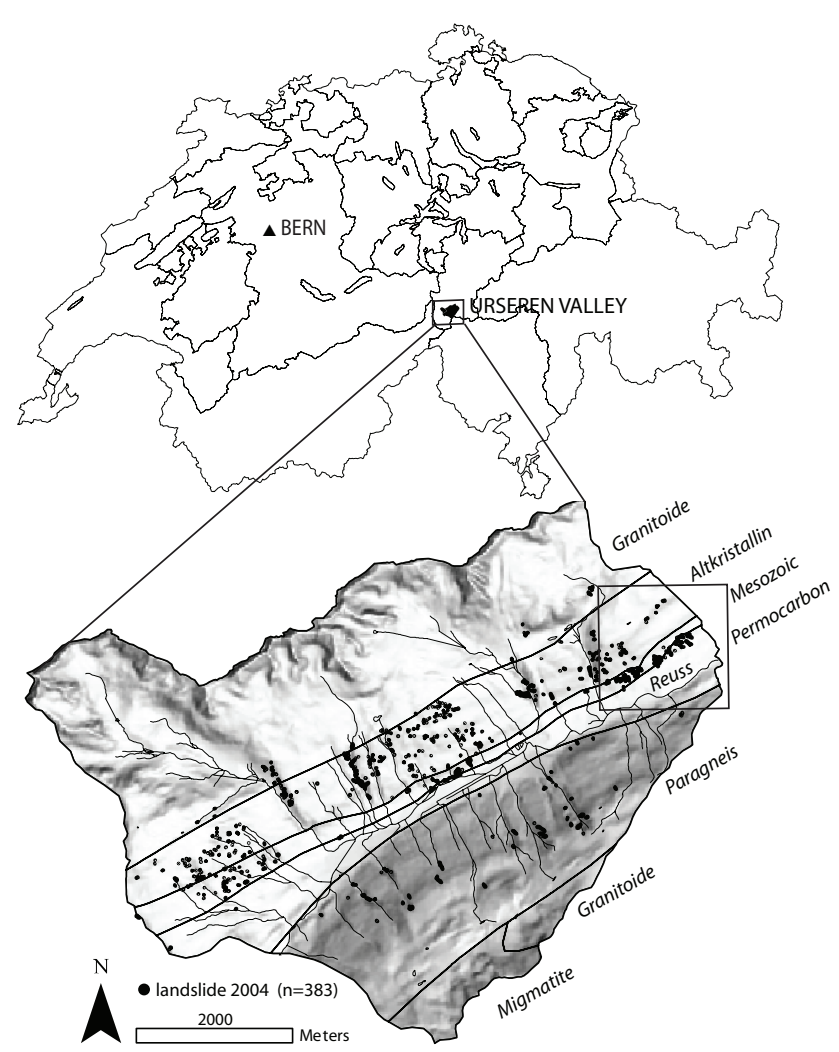

Fig. 1. Map of Switzerland and the study area (Projection: CH1903 LV03). Details on the rectangle area are shown in Fig. 3.

ments (Labhart, 1999). During the Permocarbon sandyclay sediments deposited while during the Mesozoic, different materials from the geologic periods Trias (sandstone, rauhwacke and dolomite), Lias (dark clay-marl and marl) and Dogger (clays, marl and limestone) deposited. Throughout the mountain development the materials were heavily metamorphosed to shale (Kaegi, 1973). Due to erosion of these soft layers a depression developed (Kaegi, 1973). The valley axis corresponds to the direction of the strike of the layers from SW to NE. Weathering of the calcareous material produced clay-rich soils that are prone to landslides. Riverbeds are characterised by glaciofluvial deposits. On the valley slopes, Quaternary moraines and talus fans are common and consist mainly of siliceous loamy gravel material. The reader is referred to Wyss (1986) for a detailed description of the tectonic and lithostratigrapical evolution of the region. Dominant soil types in the catchment classified after WRB (2006) are Podsols, Podzocambisols and Cambisols, often with stagic properties. Above $2000 \mathrm{~m}$ a.s.l. and on steep valley slopes, Leptosols are common (with rendzic Leptosols on the calcareous substrates). At the valley bottom and lower slopes, clayey gleyic Cambisol, partly stagnic Histosols, Fluvisols and Gleysols developed. 
Shallow translational landslides are frequent in the area. The mean area of a single landslide in 2004 is approximately $250 \mathrm{~m}^{2}$ with an average slope angle of $33.9^{\circ}$. The single landslides move along planar slip surfaces affecting soil lying upon an impermeable substratum, such as clays and marls or at the contact between regolith and bedrock. The main triggering factor is intense rainfall $>150 \mathrm{~mm}$ within 3 consecutive days (Meusburger and Alewell, 2008). Sporadic triggering of landslides occurs due to snow movement and snowmelt in spring.

The valley is characterised by a high mountain climate with a mean air temperature of $3.1^{\circ} \mathrm{C}(1901-1961)$. The mean annual rainfall at the MeteoSwiss climate station in Andermatt $\left(8^{\circ} 35^{\prime} / 46^{\circ} 38^{\prime} ; 1442 \mathrm{~m}\right.$ a.s.l. $)$, located at the outlet of the valley, is about $1400 \mathrm{~mm}_{\text {year }}{ }^{-1}$. The rainfall maximum occurs in October, the minimum in February. The valley is snow covered for 5 to 6 months (from November to April) with the maximum snow height in March. The river Reuss has a nivo-glacial runoff regime. Nevertheless, summer and early autumn floods represent an important contribution to the flow regime. The peak runoff period is in June (BAFU, 2009).

Vegetation shows strong anthropogenic influences due to grassland farming for centuries. The four main land-cover types are (i) alpine grasslands and dwarf-shrubs (64\%), (ii) scree $(16 \%)$, (iii) at higher elevations bare rock (11\%), and (iv) shrubs (8\%). Urban areas and forest cover are each less than $1 \%$ of the area. The forest was cultivated for avalanche protection above the villages. Frequently occurring avalanches are associated with the scarce forest cover. The valley has been a cultural landscape for centuries. However, land use (grassland management) has undergone decisive changes during the last decades (Meusburger and Alewell, 2008). The main developments are (i) the abandonment of remote areas, which led to an intensification of the accessible areas close to the valley bottom and (ii) a decrease of farmers, which resulted in less maintenance of the grassland areas.

\section{Concept and methods}

\subsection{Logistic regression model (LRM)}

Logistic regression predicts the probability distribution of a dichotomy dependent variable (landslide occurrence) through numeric (e.g. elevation) as well as categorical (e.g. geologic formations) predictors. For the categorical predictors dummy variables are used. The strict data requirements of discriminant analysis and linear regression (like e.g. normal distribution) are relaxed. The multiple logistic regression equation (Backhaus, 2006; Ohlmacher and Davis, 2003) is:

$$
P\left(y_{i}=1\right)=\frac{1}{1+\exp \left(-\left(b_{0}+\sum_{p=1}^{n} b_{p} x_{p i}^{+} \sum_{q=1}^{k} b_{q} z_{q i}\right)\right)}
$$

where $P$ is the probability of the occurrence dichotomy dependent variable (here 0 is for stable and 1 for instable conditions), $i$ is the number of observations (here: number of pixels), $x_{p i}, \ldots, x_{n i}$ are the values of the independent numeric predictors $x_{1}, \ldots, x_{n}$ for the i-th observation, $b_{0}, \ldots, b_{n}$ and $b_{1}, \ldots, b_{k}$ are the numeric and categorical coefficients of the logistic regression, $n$ is the number of independent numeric predictors, $z$ are values of the independent categorical predictor transformed in dummy variables equal to 1 if the specific class of the categorical predictor is present and 0 if not, and $k$ are the classes of the categorical predictor.

When using multivariate analysis multi-collinearity is a critical point. Multi-collinearity is the undesirable situation when one predictor (here: landslide causal factor) is a linear function of other predictors. Thus, a multi-collinearity diagnosis was applied prior to the logistic regression to reduce redundancy and to improve numerical stability in the subsequent analyses (Backhaus, 2006; Tasser et al., 2003) Predictors with high cross-correlations to several other predictors and with high variance inflation factors (VIF) were excluded in order to reduce collinearity. There is no fixed threshold for VIF values, but as a rule of thumb predictors with $\mathrm{VIF}<2$ can be included (Backhaus, 2006; Tasser et al., 2003). The exclusion process was guided by expert knowledge supported by a field mapping of landslides and related landslide causal factors (see Sect. 4.1). With the remaining set of independent predictors the multivariate logistic regression analysis with a stepwise forward selection method was used. The regression parameters were estimated with the maximum likelihood method.

\subsection{Procedure and database construction}

Data collection and preparation was accomplished by means of a geographic information system (GIS). We used ArcDesktop 9.2 by ESRI to visualize, superimpose, and analyse the diverse predictor maps (e.g. geology, slope, elevation, etc.).

\subsubsection{Landslide inventory maps}

The production of the landslide inventory maps of the study area $\left(30 \mathrm{~km}^{2}\right)$ was done by visually vectorising the landslide source area using aerial photographs of the different years 1959, 2000, and 2004 (Table 1). Landslide source areas $>25 \mathrm{~m}^{2}$ were mapped, rasterised and included in the analysis. The photographs had a scale of at least 1:12000. The photographs from 1959 were black and white images that were georeferenced and orthorectified with the help of ground control points, a DEM (25 m grid; vertical accuracy in the Alps of $3 \mathrm{~m}$ ) and the camera calibration protocols (Swisstopo, 2006). For the years 2000 and 2004 the 
Table 1. List of aerial photographs used for the mapping of the landslide inventory maps.

\begin{tabular}{rlrllll}
\hline $\begin{array}{r}\text { Aerial } \\
\text { photograph }\end{array}$ & $\begin{array}{l}\text { Data } \\
\text { source }\end{array}$ & Resolution & $\begin{array}{l}\text { Landslides } \\
\left(>25 \mathrm{~m}^{2}\right)\end{array}$ & $\begin{array}{l}\text { Landslide } \\
\text { area (ha) }\end{array}$ & $\begin{array}{l}\text { Mean area } \\
\left(\mathrm{m}^{2}\right)\end{array}$ & $\begin{array}{l}\text { Standard } \\
\text { deviation }\left(\mathrm{m}^{2}\right)\end{array}$ \\
\hline 22 Jul 1959 & Oswisstopo (DV063927) & $1 \mathrm{~m}$ & 190 & 5.0 & 263 & 588 \\
20 Aug 2000 & Oswisstopo (DV043734) & $0.5 \mathrm{~m}$ & 324 & 7.3 & 226 & 573 \\
9 Sep 2004 & Oswisstopo (DV043734) & $0.5 \mathrm{~m}$ & 383 & 9.4 & 246 & 566 \\
\hline
\end{tabular}

orthorectified RGB "Swissimages" with a pixel resolution of $0.5 \mathrm{~m}$ were directly used for landslide mapping without pre-correction. The landslide inventory map resulting from the orthophoto of the year 2004 was verified by ground control during field investigations in 2005. The separation of the landslide database according to landslide type (rotational, translational) was not done, because it could neither be distinguished from aerial photographs nor checked by field investigations for the dataset of 1959. During the field excursions, 27 accessible landslides were investigated in more detail. The landslide inventory map of 1959 could not be verified. However, most of the landslides in 1959 are still present today and could be compared to data of our ground truth measurements. This is due to slow regeneration of the landslides that takes about decades. The quality and reliability of the landslide inventory map generated with aerial photographs was found to be high as all landslides were correctly identified in the field. The aerial photograph interpretation method, that is a standard method for landslides mapping (Wills and McCrink, 2002), was found to be very suitable for the investigation area due to the low percentage of forest cover. In 1959, 190 shallow landslides $\left(>25 \mathrm{~m}^{2}\right)$ were present. In 2000 the number of landslides increased to 324 and in 2004, 383 shallow landslides were mapped.

\subsubsection{Landslide causal factors maps}

Several of the causal factor maps are derivates of the DEM (slope aspect, elevation, curvature, morphologic index and slope angle) and were calculated with a three-pixel square kernel. The morphologic index is a classification of the slope and curvature map into the topographic features: peak, ridge, pass, plane, channel, or pit. Further derivates of the slope and aspect map are the flow direction and the flow length, which is the distance along a flow path. The flow accumulation is based on the number of cells flowing into each cell in the output raster. In addition, topographic wetness index was used, which is defined as $\ln (\alpha / \tan \beta)$ where $\alpha$ is the local upslope area draining through a certain point per unit contour length (here the flow accumulation) and $\beta$ is the local slope (Beven and Kirkby, 1979). The VECTOR25 dataset of Swisstopo offers vector data of rivers, roads and land-cover. It is based on a 1:25 000 map (position accuracy 3-8 m) of 1993, thus, it was updated with the aerial photograph of 2004 to reflect the present-day land-cover situation. The land-cover map (consisting of the categories grassland, forest, shrub, rock, debris, snow and water) was converted to raster format ( $25 \mathrm{~m}$ raster resolution). Another land-cover map constructed from the aerial photograph of the year 1959 was used in the logistic regression model of 1959 because land-cover changed during the last decades. Land-cover and the pasture maps (consisting of the categories Freiberg, private land, sheep-, goatand cattle pasture and cattle alp) were the only causal factor maps variable over time. The remaining causal factor maps were identical and used for the logistic regression of both years, 1959 and 2000. Raster maps of the distance from river and roads were obtained with ArcGIS distance and density functions (with a $500 \mathrm{~m}$ moving window). Point density and line density calculate the quantity that falls within the identified neighbourhood (here $500 \mathrm{~m}$ ) and divide that quantity by the area of the neighbourhood. ArcGIS density functions were also used to obtain a raster map of avalanche density. The avalanches that occurred since 1695 (data source: Swiss Federal Institute for Snow and Avalanche Research) were averaged for each pixel with a $500 \mathrm{~m}$ moving window to generate the avalanche density map. The factor map geology was created based on the definition of geologic formations by Labhart (1999) and refined by field and aerial photograph mapping. Thus, for the lower accessible formations (Mesozoic, Permocarbon) mapping scale could be improved from 1:200 000 to 1:25000. A geomorphologic map (consisting of the categories alluvium, debris fan, moraine, hillside colluvial deposit and solid rock) was generated based on a Quaternary map with a scale of 1:33000 (Fehr, 1926) and the aerial photographs. The revised geologic and geomorphologic maps, originally in vector format, were then converted to raster format. Tectonic fault lines were digitized (Labhart, 1999) and the map of the distance from those was calculated and stored as a raster map. The present and past land use was determined with pasture maps of the years 1955 and 2006 (Russi, 2006) that were digitised, georeferenced, and rasterised. The precipitation map used is based on long-term (1961-1991) mean precipitation data (@Hydrological Atlas of Switzerland, Swiss Federal Office for the Environment). The resolution of data points is very coarse $(1 \mathrm{~km})$, thus, inverse distance weighted (IDW) interpolation was used to determine cell values. This map shows an east-west gradient, ranging from about $1800 \mathrm{~mm}_{\text {year }}{ }^{-1}$ in the western part, to about $1400 \mathrm{~mm}_{\text {year }}{ }^{-1}$ in the eastern part. No elevation gradient is evident. Further information about these maps and data origins is presented in Table 2. 
Table 2. List of the considered predictors and search radius applied for the generation of the map, data scale/resolution, evidence of multicollinearity $(\mathrm{O}=$ independent predictors; $\mathrm{X}=$ excluded predictors due to multi-collinearity), significance (Sig) of the predictors for the logistic regression model $(\mathrm{LRM})$ of 2000 and $1959\left(^{* * *}=P<0.001\right)$.

\begin{tabular}{|c|c|c|c|c|c|c|c|}
\hline No. & Predictors & Data source & Search radius & $\begin{array}{l}\text { Scale/ } \\
\text { Resolution }\end{array}$ & $\begin{array}{l}\text { Inde- } \\
\text { pen- } \\
\text { dent }\end{array}$ & $\begin{array}{l}\text { Sig } \\
\text { LRM } \\
2000\end{array}$ & $\begin{array}{l}\text { Sig } \\
\text { LRM } \\
1959\end{array}$ \\
\hline 1 & Elevation & DHM25@swisstopo (DV002234.1) & 3 raster kernel & $1: 25000$ & $\mathrm{X}$ & & \\
\hline 2 & Aspect & DHM25@swisstopo (DV002234.1) & 3 raster kernel & $1: 25000$ & $\mathrm{O}$ & & \\
\hline 3 & Slope & DHM25@swisstopo (DV002234.1) & 3 raster kernel & $1: 25000$ & $\mathrm{O}$ & $* * *$ & $* * *$ \\
\hline 4 & Curvature & DHM25@swisstopo (DV002234.1) & 3 raster kernel & 1:25000 & $\mathrm{X}$ & & $* * *$ \\
\hline 5 & Flow length & DHM25@swisstopo (DV002234.1) & & $1: 25000$ & $\mathrm{X}$ & & \\
\hline 6 & Morphologic index & DHM25@swisstopo (DV002234.1) & 3 raster kernel & $1: 25000$ & $\mathrm{X}$ & & \\
\hline 7 & Flow accumulation & DHM25@swisstopo (DV002234.1) & & $1: 25000$ & $\mathrm{O}$ & 0.07 & \\
\hline 8 & Flow direction & DHM25@swisstopo (DV002234.1) & 3 raster kernel & 1:25000 & $\mathrm{X}$ & & \\
\hline 9 & Topographic wetness index & DHM25@swisstopo (DV002234.1) & & $1: 25000$ & $\mathrm{X}$ & & \\
\hline 10 & Stream-density & VECTOR25@swisstopo (DV002213) & $500 \mathrm{~m}$ & $1: 25000$ & $\mathrm{O}$ & $* * *$ & $* * *$ \\
\hline 11 & Distance to stream & VECTOR25@swisstopo (DV002213) & & $1: 25000$ & $\mathrm{O}$ & & \\
\hline 12 & Road-density & VECTOR25@swisstopo (DV002213) & $500 \mathrm{~m}$ & $1: 25000$ & $\mathrm{O}$ & $* * *$ & \\
\hline 13 & Distance to roads & VECTOR25@swisstopo (DV002213) & & 1:25000 & $\mathrm{O}$ & 0.03 & \\
\hline \multirow[t]{2}{*}{14} & Land-cover 2000 & $\begin{array}{l}\text { based on VECTOR25@swisstopo } \\
\text { (DV002213) and aerial photograph (2000) }\end{array}$ & & $<1: 25000$ & $\mathrm{X}$ & & \\
\hline & Land-cover 1959 & based on aerial photograph (1959) & & $<1: 25000$ & & & \\
\hline 15 & Geologic formation & changed after Labhart (1999) & & $\begin{array}{l}1: 25000 \\
1: 200000\end{array}$ & $\mathrm{O}$ & $* * *$ & $* * *$ \\
\hline 16 & Distance to fault line & Labhart (1999) & & 1:200000 & $\mathrm{X}$ & & \\
\hline 17 & Quaternary & based on Fehr (1926) & & $1: 33000$ & $\mathrm{X}$ & & \\
\hline 18 & Mean precipitation & (C) Hydrological Atlas of Switzerland & & $1 \mathrm{~km}$ grid & $\mathrm{X}$ & & \\
\hline 19 & Avalanche density & $\begin{array}{l}\text { Swiss Federal Institute for Snow } \\
\text { and Avalanche Research (SLF) }\end{array}$ & $500 \mathrm{~m}$ & & $\mathrm{O}$ & 0.002 & $* * *$ \\
\hline 20 & Pasture maps 1955, 2006 & Korporation Urseren; Andermatt & & $1: 25000$ & $\mathrm{X}$ & & \\
\hline
\end{tabular}

\subsubsection{Data analysis}

All georeferenced raster maps (landslide causal factor maps and landslide inventory maps) were resampled with a reference raster to guarantee a correct allocation of the pixel centroids of the different maps. The grid cells of the reference raster contained unique integer values. The reference raster was superimposed with the causal factors and the landslide inventory maps by the ArcGIS function "combine". The result is a numbered data matrix where the rows represent the number of grid-cells and the columns contain the attributes of the predictor maps at the grid location plus the information of the inventory map. The resulting two data matrices (1959, 2000) were randomly split into a calibration and validation data set. More details on the model validation is given in the next section. For the logistic regression analysis we used the statistical software package SPSS (version 15.0). Finally, the logistic regression equation was entered in the ArcDesktop raster calculator to produce the landslide susceptibility map for the entire region by means of the most significant landslide causal factors. The predicted probabilities for the investigation area were classified into five different susceptibility zones with very low susceptibility for probabilities between 0.0 and 0.15 , low susceptibility for 0.15 to 0.35 , medium from 0.35 to 0.65 , high between 0.65 and 0.85 and very high susceptibility for probability of 0.85 to 1.0 .

\subsection{Validation based on temporal and spatial strategies}

The success rate is commonly used in evaluating cell-based landslide susceptibility model performance. It is based on the ratio of successfully predicted landslide sites over total actual landslide sites. However, Fabbri et al. (2003) pointed out that this is not a verification of the predictive value. For validation of the predictive power of the model, a comparison between the map (model) obtained and independent landslide data, which is more recent than the used model set is necessary. The comparison can be qualitative - for instance by a visual overlay - or quantitative, using different indices such as area of a class affected by landslides per total area of class (Suezen and Doyuran, 2004; Yesilnacar and Topal, 2005; Zhou et al., 2002), a confusion matrix (Carrara, 1983; 


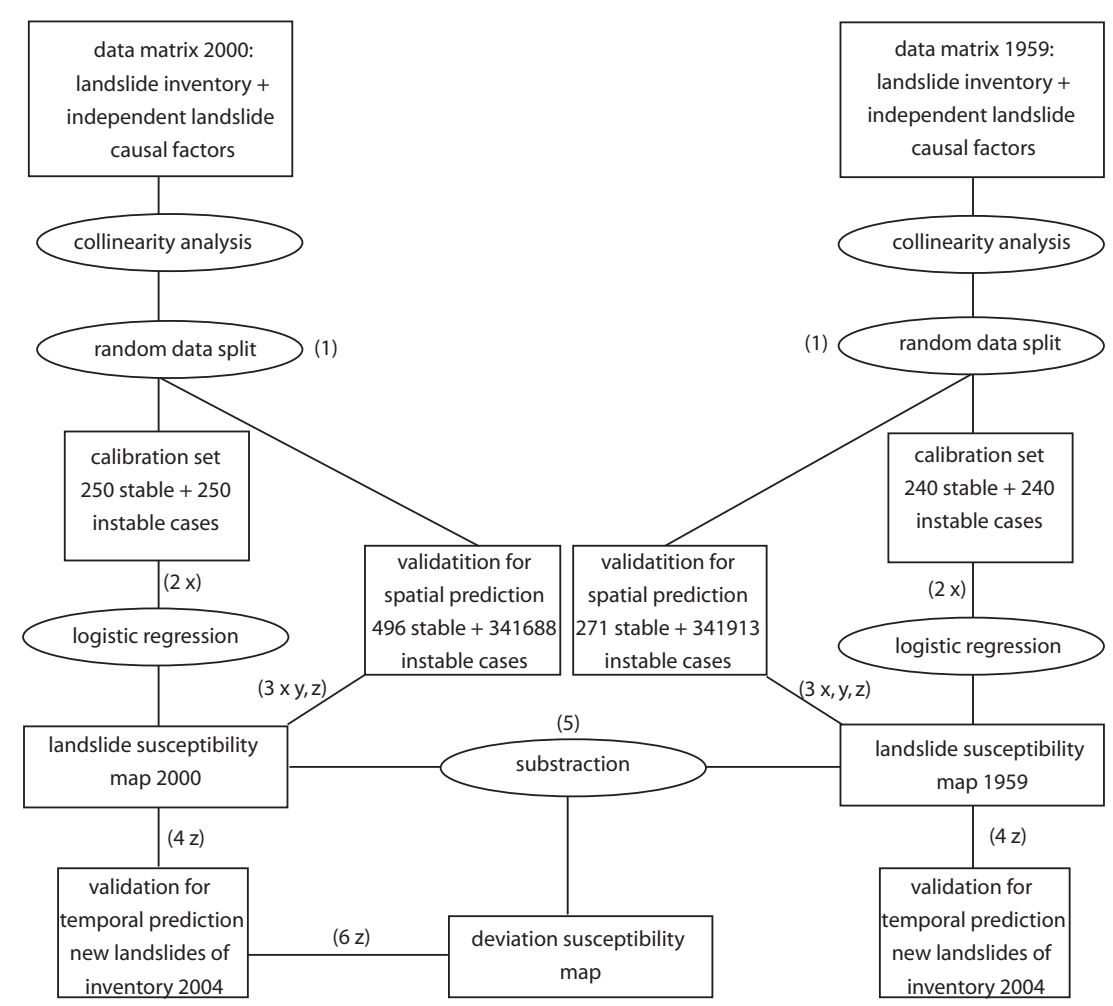

Fig. 2. Evaluation steps of the logistic regression models of 1959 and 2000. The ellipses show processes and the rectangles results. The numbers and letters refer to the explanation given in the text.

Carrara et al., 2003) or by using the Receiver Operating Characteristic (ROC) curve (Chung and Fabbri, 2003; Fabbri et al., 2003). We applied these methods to assess the accuracy of the susceptibility maps. With the statistical software the percentage of correctly classified instable and stable grid cells is given as weighted average in a confusion matrix ( $\mathrm{x}$, Fig. 2) and ROC curves of the predicted probabilities were plotted (y, Fig. 2). With the GIS the Spearman's rank correlation between the modelled susceptibility zones and observed percentage landslide density in these zones is assessed ( $\mathrm{z}$, Fig. 2). Chung and Fabbri (2003) proposed three strategies to obtain an independent validation dataset: (a) landslides of the study area are randomly split into two groups, one for analysis (calibration) and one for validation (b) the analysis is carried out using landslides occurred in a certain period and validation is performed by means of landslides occurred in a different period (c) the analysis is carried out in a part of the study area and the obtained map (model) is validated in another part. The temporal validation strategy (b) permits testing the predictive capability of a model (Remondo et al., 2003). In this study, we used the random split approach (a) to test the validity of the prediction for extrapolation in space and the approach (b) to test the validity of the model for the extrapolation over time. The following six evaluation steps were executed (Fig. 2):
1. We applied a random split of the entire dataset (for 1959 and 2000 data separately). Approximately $33 \%$ of instable grid cells and an equal amount of stable ones were used to setup the LRMs. The remaining dataset was retained for spatial validation.

2. We setup LRMs for the years 1959 and 2000 and determined the "goodness of the fit" or "success rate" of both models by means of maximum likelihood classification with the independent causal factor maps The number of "selected cases", here grid cells randomly selected for the model setup are shown in Table 3. A comparison between the number of stable (0) and instable (1) predictions between model and inventory data is shown as percentage in the third column.

3. Validation of the LRM for the spatial prediction, was done with the independent data set obtained by the random split ("unselected cases", Table 3). The percentage of correct predictions is shown in the 6th column.

4. To evaluate the predictability of the LRM of 1959 and 2000 for extrapolation in time, we used the independent 52 new landslides that occurred between 2000 and 2004 (Table 1). These landslides were mapped on the aerial photograph of 2004. 
Table 3. Classification of stable (0) and instable (1) cases (here pixels) by the three most significant predictors of the two logistic regression models (1959 and 2000).

\begin{tabular}{|c|c|c|c|c|c|c|c|c|}
\hline & \multirow[t]{2}{*}{ Observed } & & \multicolumn{3}{|c|}{ Selected Cases } & \multicolumn{3}{|c|}{ Unselected Cases } \\
\hline & & & $\begin{array}{r}0 \\
\text { stable }\end{array}$ & $\begin{array}{r}1 \\
\text { instable }\end{array}$ & $\begin{array}{r}\text { correct } \\
(\%)\end{array}$ & $\begin{array}{r}0 \\
\text { stable }\end{array}$ & instable & $\begin{array}{r}\text { correct } \\
(\%)\end{array}$ \\
\hline \multicolumn{9}{|l|}{2000} \\
\hline Step 1 & $\begin{array}{l}\text { Geologic formation } \\
\text { Overall percentage }\end{array}$ & $\begin{array}{l}0 \\
1\end{array}$ & $\begin{array}{r}131 \\
35\end{array}$ & $\begin{array}{l}119 \\
215\end{array}$ & $\begin{array}{l}52.4 \\
86.0 \\
69.2\end{array}$ & $\begin{array}{r}183280 \\
42\end{array}$ & $\begin{array}{r}158408 \\
454\end{array}$ & $\begin{array}{l}53.6 \\
91.5 \\
53.7\end{array}$ \\
\hline Step 2 & $\begin{array}{l}\text { Slope } \\
\text { Overall percentage }\end{array}$ & $\begin{array}{l}0 \\
1\end{array}$ & $\begin{array}{r}169 \\
40\end{array}$ & $\begin{array}{r}81 \\
210\end{array}$ & $\begin{array}{l}67.6 \\
84.0 \\
75.8\end{array}$ & $\begin{array}{r}232275 \\
55\end{array}$ & $\begin{array}{r}109413 \\
441\end{array}$ & $\begin{array}{l}68.0 \\
88.9 \\
68.0\end{array}$ \\
\hline Step 3 & $\begin{array}{l}\text { Stream-density } \\
\text { Overall percentage }\end{array}$ & $\begin{array}{l}0 \\
1\end{array}$ & $\begin{array}{r}176 \\
40\end{array}$ & $\begin{array}{r}74 \\
210\end{array}$ & $\begin{array}{l}70.4 \\
84.0 \\
77.2\end{array}$ & $\begin{array}{r}240328 \\
67\end{array}$ & $\begin{array}{r}101360 \\
429\end{array}$ & $\begin{array}{l}70.3 \\
86.5 \\
70.4\end{array}$ \\
\hline Step 7 & Overall percentage & & & & 81.4 & & & 74.5 \\
\hline \multicolumn{9}{|l|}{1959} \\
\hline Step 1 & $\begin{array}{l}\text { Geologic formation } \\
\text { Overall percentage }\end{array}$ & $\begin{array}{l}0 \\
1\end{array}$ & $\begin{array}{r}140 \\
25\end{array}$ & $\begin{array}{l}100 \\
215\end{array}$ & $\begin{array}{l}58.3 \\
89.6 \\
74.0\end{array}$ & $\begin{array}{r}200717 \\
27\end{array}$ & $\begin{array}{r}141215 \\
244\end{array}$ & $\begin{array}{l}58.7 \\
90.0 \\
58.7\end{array}$ \\
\hline Step 2 & $\begin{array}{l}\text { Slope } \\
\text { Overall percentage }\end{array}$ & $\begin{array}{l}0 \\
1\end{array}$ & $\begin{array}{r}171 \\
33\end{array}$ & $\begin{array}{r}69 \\
207\end{array}$ & $\begin{array}{l}71.3 \\
86.3 \\
78.8\end{array}$ & $\begin{array}{r}248111 \\
38\end{array}$ & $\begin{array}{r}93821 \\
233\end{array}$ & $\begin{array}{l}72.6 \\
86.0 \\
72.6\end{array}$ \\
\hline Step 3 & $\begin{array}{l}\text { Stream-density } \\
\text { Overall percentage }\end{array}$ & $\begin{array}{l}0 \\
1\end{array}$ & $\begin{array}{r}185 \\
49\end{array}$ & $\begin{array}{r}55 \\
191\end{array}$ & $\begin{array}{l}77.1 \\
79.6 \\
78.3\end{array}$ & $\begin{array}{r}255641 \\
51\end{array}$ & $\begin{array}{r}86291 \\
220\end{array}$ & $\begin{array}{l}74.8 \\
81.2 \\
74.8\end{array}$ \\
\hline Step 5 & Overall percentage & & & & & 82.3 & & 76.3 \\
\hline
\end{tabular}

5. In order to extract the influence of dynamic landslide causal factors on landslide susceptibility, the susceptibility zones of LRM of 1959 were subtracted from the ones of the LRM of 2000. We know that in 1959, the traditional land use was still present (Russi, 2006) and assume that the effects of climate change were less than today (IPCC, 2007). Hence, the susceptibility map of 1959 shows more the traditional long established susceptibility situation compared to today's situation. In contrast, the susceptibility zones, based on the landslide inventory map of 2000 already include new susceptibility zones due to impact of dynamic factors. This map is already a combination of the initial traditional and "human-induced" susceptibility. Thus, we hypothesise that by subtracting the susceptibility zones of the LRM of 1959 from the LRM of 2000 the obtained map (called "deviation susceptibility map") displays the shift of susceptibility zones over time. This shift over time is due to the influence of dynamic landslide causal factors, e.g. the relevance of landslide causal factors change over time.
6. To confirm this hypothesis, the obtained deviation susceptibility map is validated with the set of 52 new landslides that occurred between the year 2000 and 2004.

\section{Results and discussion}

\subsection{Field mapping of potential landslide causal factors}

In the Urseren Valley, many potential landslide causal factors are spatially correlated, thus, prior to the statistical analysis a mapping of potential landslide causal factors in the field was done to assist the exclusion process of inter-correlated predictors (Fig. 3). In the Urseren Valley (shallow) translational landslides are predominant. These landslides are very frequent in the foot zone of the south-facing slope, where return flow in form of small springs causes relatively high water saturation in the soils. The highly instable calcareous material of the Mesozoic layer weathers to clay minerals, which further favours the development of layered stagnic soils. During field observations, we found that about $80 \%$ of the 27 landslides had small springs and stagnic soils at the tear-off line. In addition, land use type changes within this 
zone. Where the slopes become too steep for mowing by machines they are intensively pastured. A fence separates the meadows close to the valley floor from the pastures. Pasturing was observed to have several effects possibly related to soil stability (Pietola et al., 2005): trampling leads to (i) a compacting of the soil and the development of a water retaining horizon, (ii) the retention of water is further raised by the micro topography of the trails, and (iii) the reduction of the vegetation cover. Stagnic soils and the occurrence of return flow would probably be good predictors for landslides. However, to derive these parameters for the entire catchment would be very work intensive. Furthermore, most of the area is difficult to access. Therefore, these parameters need to be replaced by other related parameter maps that could be spatially derived from GIS tools. For example the likelihood of return flow can be represented by the topographic wetness index (Beven and Kirkby, 1979).

\subsection{Results of the logistic regression analysis}

The setup of the logistic regression model of 2000 (LRM 2000) was accomplished based on the landslide inventory map of 2000 and 20 static causal factor maps. During multi-collinearity analysis, 11 predictors were excluded from further analysis due to multi-collinearity. Column 5 in Table 2 displays the inter-correlating predictors. For instance, an inter-correlation between elevation and land-cover was observed; the higher the area the less grass- and the more rock surfaces are present. However, there is no causal relationship between landslide occurrence and elevation. Hence, the elevation was excluded from further analysis. After the model generation with the stepwise forward selection method, seven of nine predictors were included due to a significant explanation of the variance (Table 2): geology, slope, stream-density, road-density, avalanche density, distance to roads and flow accumulation. With this set of seven predictors, a success rate of $81.4 \%$ was achieved (selected cases; Table 3). The logistic regression model of 1959 (LRM 1959) identified five significant predictors (geology, slope, streamdensity, avalanche density, and curvature) with a success rate of $82.3 \%$. The three most significant predictors are identical to the LRM of 2000.

Both pasture maps are highly correlated with the geologic map. Including the pasture map of 1955 instead of geology into the LRM of 2000 achieved a success rate of $68.6 \%$. The described effects of pasturing on the conditioning of landslides (Sect. 4.1) are related to trampling and, thus, to pasture intensity. However, the pasture maps do not display pasture intensity and its variability within the single classes of the map. Moreover, even within same classes management was not static. For the single pasture maps as well as derived land use change maps could not be quantified and, thus, were no suitable predictors for the multivariate analysis. Nonetheless, the pasture map information is useful to interpret the deviation susceptibility map (see below).

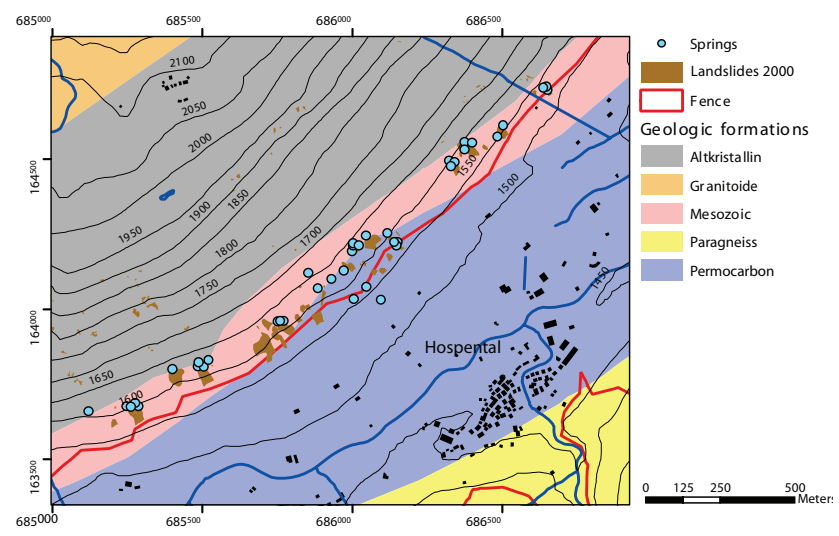

Fig. 3. Slope section near Hospental showing the overlap of some landslide causal factors: geologic formation, topography, springs, and land use (below the fence meadows; above the fence pasturing). The location of the area is shown by rectangle in Fig. 1.

We found, that in correspondence to many other studies the most significant predictors are slope and geology to explain landslide susceptibility (Ayalew and Yamagishi, 2005; Carrara et al., 1991; Clerici et al., 2006; Dai and Lee, 2002; Komac, 2006; Ohlmacher and Davis, 2003; Santacana et al., 2003; Van Westen and Lulie Getahun, 2003; Zhou et al., 2002; Rickli et al., 2001; Suezen and Doyuran, 2004). These predictors can be physically explained with the equation for the critical altitude $H_{C}$ for slopes (Carson, 1971):

$H_{c}=\frac{4 c \sin \chi \cos \Phi}{\gamma *(1.0-\cos (\chi-\Phi)}$

where $c$ is cohesion, $\gamma$ is bulk density, $\chi$ is slope and $\Phi$ is friction angle. The equation describes slope stability as a function of soil strength (cohesion and friction angle) and shear forces (density and slope). A slope/soil becomes instable if the actual height/thickness exceeds the critical height. The higher the slope angle and the greater the soil depth, the higher becomes shear force and the less stable becomes the slope.

A further significant predictor in our study is streamdensity. The balance between soil strength and shear force is a function of soil water content (Kemper and Rosenau, 1984). Wet places and hollows where water can infiltrate are especially prone to landslides (Fig. 3). Stream-density as well as flow-accumulation are proxy variables for the important physical parameter of "soil water content" in the statistical model. With increasing density of the stream network, water saturation and the occurrence of return flow increases, which results in two processes that potentially decrease soil stability: positive pore water pressure, which reduces cohesion of soil particles $(c)$, and heavier soils that increase the bulk density $(\gamma)$.

Furthermore, soil strength parameters are influenced by parent material, which is represented by geology in the 
model. Geology was found to be the most important predictor as it appears to be most important for the material properties and additionally effects runoff generation. Minor improvements of the model are yielded by the predictor maps distance to roads and road density, which explain the occurrence of few landslides due to constructional interferences. Road distance and road density maps may show high variability over time (Petley et al., 2007). However, in Urseren Valley where the road networks remained basically identical during the last fifty years.

Avalanche density (since 1695) is a further predictor, which improved the explained variance of the landslide distribution. Avalanches are regarded as potential landslide causal factors because of the additional friction forces that may trigger tension fissures. A spatial relationship is evident even though the causal relation is questionable because stability of snow cover depends on similar topographical conditions as the stability of soil cover (Meusburger and Alewell, 2008).

\subsection{Validation of the landslide susceptibility model for spatial predictions}

With all seven predictors $74.5 \%$ of the validation data set for the LRM of 2000 could be correctly predicted. If the three most significant predictors (geology, slope and streamdensity) were used for the production of the susceptibility map (selected cases), the validation procedure (unselected cases, see Table 3 ) produced only slightly worse results. In total $70.4 \%$ of the observations could be accurately classified, thereof $70.3 \%$ of the non-erodible sites and $86.5 \%$ of the erodible sites were correctly assigned. Overall, $53.7 \%$ of the observations were correctly classified with geology alone. Slope increased the explained spatial variance to $68.0 \%$ and stream-density to $70.4 \%$. Areas, which are stable today, but were predicted as being instable by the model, can be interpreted as the hazard zones for future management considerations.

In addition to the regression coefficients (Table 4, for discussion see below), the logistic regression model yields a map of probabilities expressed by numbers that are constrained to fall between 0 and 1 . The closer the numbers are to 1 , the higher is the probability for a landslides. We chose a subdivision of the probabilities obtained into five susceptibility zones. A visual comparison between the landslide susceptibility map and the landslide inventory map of 2000 indicates a good agreement (Fig. 4). The exceptions are two clusters of landslides located at the border of geologic formation of the Altkristallin and the granite of the Aare system. This might be due to the lower spatial accuracy of the geologic map in the upper part of the study area, as explained in Sect. 3.2. To evaluate the performance of the susceptibility mapping methods, the method of the Relative Operating Curve (ROC) was used (Table 5; Fig. 5; left panel). The area under the curve for the LRM 1959 and 2000 is 0.86 , which

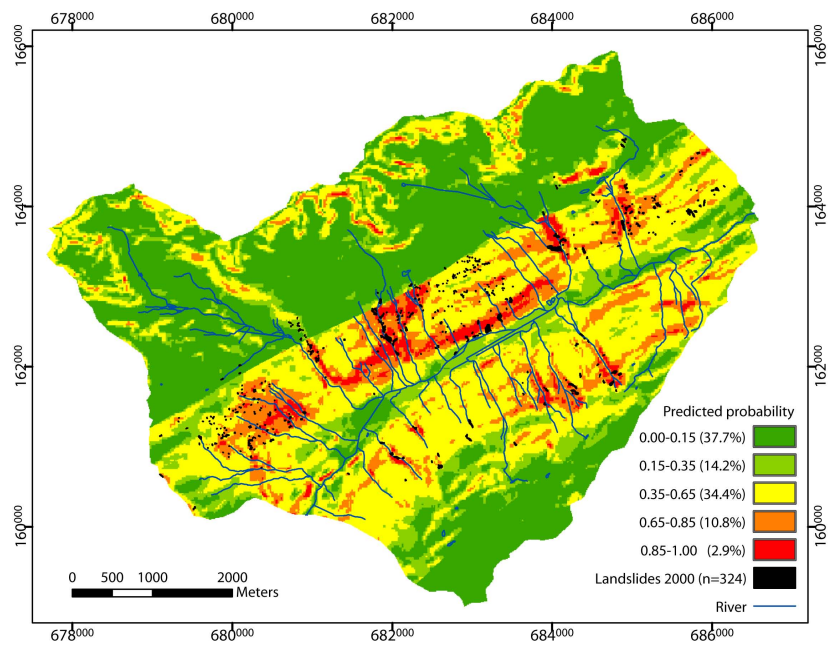

Fig. 4. Final landslide susceptibility map obtained with logistic regression model of 2000 for the $30 \mathrm{~km}^{2}$ sub-catchment (Projection: CH1903 LV03).

Table 4. Regression coefficients (b) and significance (Sig) for the parameters stream-density (Denstr), slope, and five geologic units ( $1=$ granite of the Aare system, $2=$ Altkristallin, $3=$ Mesozoic, $4=$ Permocarbon, $5=$ gneiss of the Gotthard system) of the two logistic regression models.

\begin{tabular}{|c|c|c|c|c|c|c|}
\hline \multirow[t]{2}{*}{ Predictors } & \multicolumn{3}{|c|}{ Model 2000} & \multicolumn{3}{|c|}{ Model 1959} \\
\hline & $b$ & Sig & $\operatorname{Exp}(b)$ & $b$ & Sig & $\operatorname{Exp}(b)$ \\
\hline Den & 2.15-E01 & 3.54-E05 & $124, \mathrm{E} \Omega 0$ & 4.50-E01 & 1.17 -E10 & \\
\hline Sloo & 1 & $1.30-\mathrm{E} 15$ & & & 3.27-E13 & \\
\hline Geo & & 3.56-E10 & & & $5.09-\mathrm{E} 13$ & \\
\hline Geo (1) & $2.96+\mathrm{E} 00$ & 8.14-E01 & $1.93+\mathrm{E} 01$ & $1.75+\mathrm{E} 01$ & 9.99-E01 & $4.15+\mathrm{E} 07$ \\
\hline Geo (2) & $5.59+\mathrm{E} 00$ & 6.57-E01 & $2.67+\mathrm{E} 02$ & $2.04+\mathrm{E} 01$ & 9.99-E01 & 7.24+E08 \\
\hline Geo (3) & $5.90+\mathrm{E} 00$ & 6.39-E01 & $3.66+\mathrm{E} 02$ & $1.86+\mathrm{E} 01$ & 9.99-E01 & $1.17+\mathrm{E} 08$ \\
\hline Geo (4) & $5.87+\mathrm{E} 00$ & 6.41-E01 & $3.55+\mathrm{E} 02$ & $1.81+\mathrm{E} 01$ & 9.99-E01 & $7.18+\mathrm{E} 07$ \\
\hline Geo ( & $5.38+\mathrm{E} 00$ & 6.69-E01 & $2.17+\mathrm{E} 02$ & $2.00+\mathrm{E} 01$ & 9.99-E01 & $5.06+\mathrm{E} 08$ \\
\hline Constant & $-9.37+\mathrm{E} 00$ & 4.56-E01 & 8.49-E05 & $-2.44+\mathrm{E} 01$ & 9.99-E01 & 2.60-E11 \\
\hline
\end{tabular}

is very satisfactory (it is quite close to the ideal value of 1.0). Also as seen from the table the asymptotic significance is less than 0.0001 , which means that using the probability model is much better than guessing.

Also the comparison between the modelled landslide probability and the actual landslide density in 2000 (Fig. 5; middle panel) showed good correspondence, which is expressed in a significant correlation $(P<0.01)$ between observed landslide density and predicted landslide probability.

The prediction for the extrapolation in space with the three most significant predictors of the LRM of 1959 produced slightly better validation results of $74.8 \%$ correct predictions (see unselected cases in Table 3). The regression coefficients (b) of the two LRMs are presented in Table 4 together with the odds ratio $(\operatorname{Exp}(b))$ and the significance. 

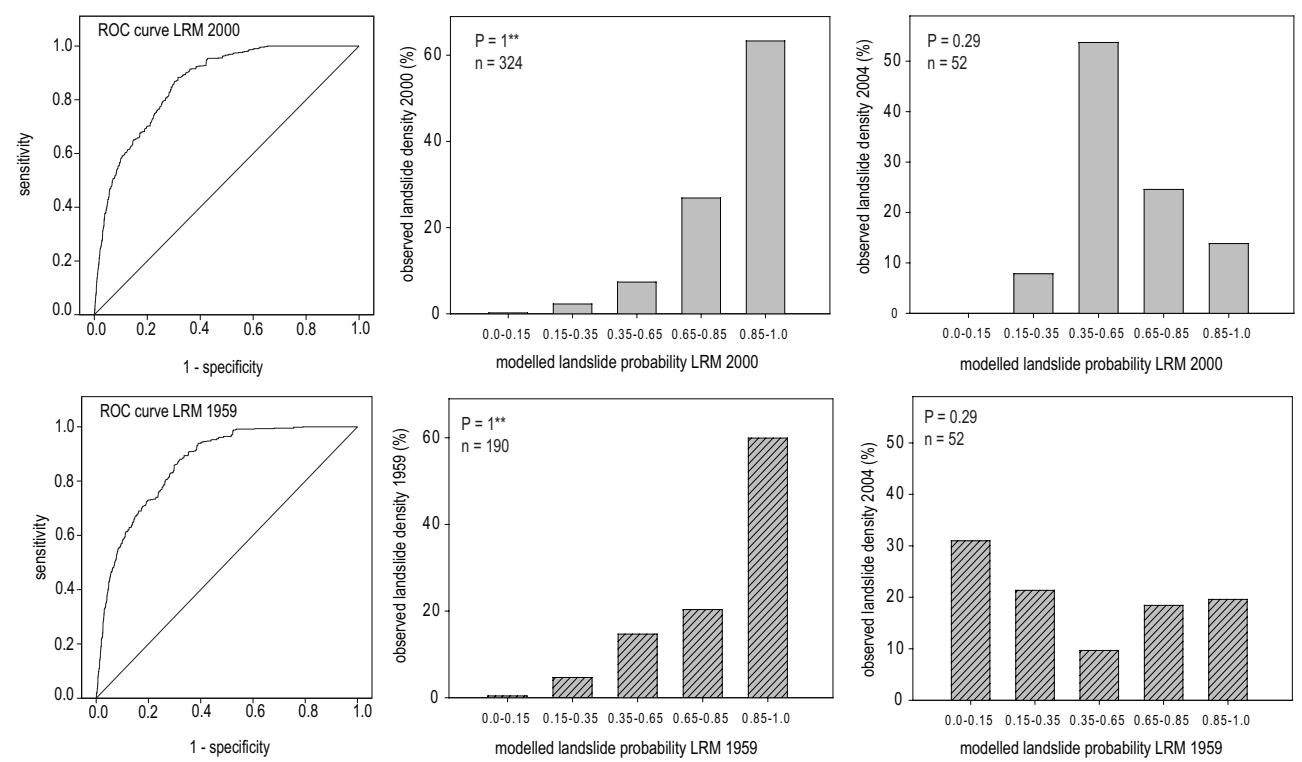

Fig. 5. Receiver operating characteristic (ROC) curves for the two logistic regression models (left) and dependency of modelled landslide susceptibility and actual landslide densities (Spearman's rank correlation coefficient $(P)$; ${ }^{* *}$ correlation is significant at a 0.01 level). The landslide density values are based on 324 mapped landslides for the year 2000 (upper part), 190 mapped landslides for the year 1959 (lower part), and 52 mapped landslides for the period 2000-2004 (right).

Table 5. Test result variable "predicted probability" by LRM 2000 and 1959.

\begin{tabular}{|c|c|c|c|c|c|}
\hline \multirow[t]{2}{*}{ LRM } & \multirow[t]{2}{*}{ Area } & \multirow[t]{2}{*}{$\begin{array}{l}\text { Std. } \\
\text { Error }\end{array}$} & \multirow[t]{2}{*}{$\begin{array}{l}\text { Asymptotic } \\
\text { Sig. }^{\text {a }}\end{array}$} & \multicolumn{2}{|c|}{$\begin{array}{l}\text { Asymptotic 95\% } \\
\text { Confidence Interval }\end{array}$} \\
\hline & & & & $\begin{array}{l}\text { lower } \\
\text { bound }\end{array}$ & $\begin{array}{l}\text { upper } \\
\text { bound }\end{array}$ \\
\hline 2000 & .861 & .005 & .000 & .851 & .872 \\
\hline 1959 & .864 & .006 & .000 & .852 & .876 \\
\hline
\end{tabular}

${ }^{\mathrm{a}}$ Null hypothesis: true area $=0.5$.

\subsection{Validation of the landslide susceptibility model for temporal predictions}

To test the suitability of the model for the prediction of future events, we compared the produced landslide susceptibility map of 2000 with the "new landslides" that occurred after 2000 until 2004. It is presumed that a spatial database containing the distribution of all the landslides over a period can be used to predict the distribution of future landslides over a period of the same length (Fabbri et al., 2003). This presumption is critical for the LRM of 1959. Accordingly there is no relation between the observed new landslides in 2004 and the predicted probability be the LRM 1959 (Fig. 5, right panel). For the LRM of 2000 the presumption is valid, nonetheless, the prediction of the new landslides was rather unsatisfactory. This is illustrated by the weak relationship $(P=0.29)$ and the loss of significant correlation (at the 0.01 level) between predicted landslide probability and observed landslide density in 2004 (Fig. 5, right panel). The new landslides occurred mainly in the zone that was predicted with only medium susceptibility. This could indicate a loss of prediction quality and the decrease of predictive power of the landslide causal factors with time.

Temporal validation adds a time element to susceptibility maps and makes the transfer to a landslide hazard map possible (Remondo et al., 2003). However, the susceptibility map failed to predict the new landslides. Thus, another approach was needed to introduce a temporal component to the susceptibility map in order to allow prediction of future landslides.

\subsection{Effect of temporal change on the probability of landslides}

In order to confirm our hypothesis that the recent landslides are a result of the increasing influence of dynamic factors and not an accidental deviation of the predicted probability, we subtracted the modelled susceptibility zones of the LRM of 2000 from the zones of the LRM of 1959. The result is a map, which shows the deviations of the susceptibility zones between the two LRMs and, thus, the change of susceptibility over time (Fig. 6). The values are negative where the landslide susceptibility zones was lower (indicating less landslide probability) in 1959 and positive where it was higher. The landslide susceptibility mainly increased near the valley bottom and the adjacent lower slopes, a decrease is visible for the more remote slopes except for the higher elevated areas with high rock and debris content that behaved unchanged. 


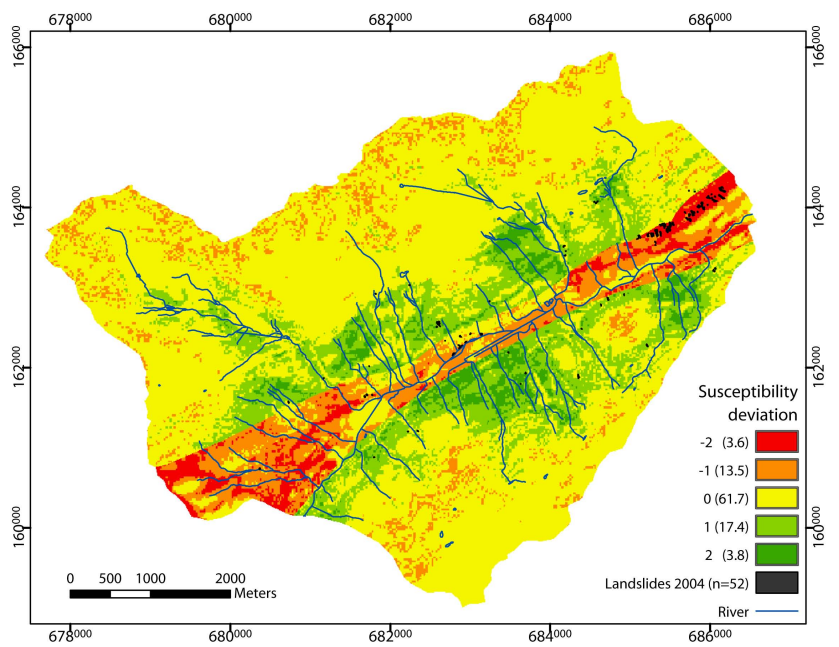

Fig. 6. Differences of susceptibility zones between the logistic regression models of 1959 and 2000 (Projection: CH1903 LV03).

The deviation susceptibility map shows good correspondence with the new landslides that predominantly occurred at the foot of the slope after 2000 (Fig. 6). About $85 \%$ of the new landslides occurred in the zone with the highest susceptibility deviation (value: -2 ) towards an increased landslide probability over time. We interpreted the obtained agreement of the deviation susceptibility map with the occurrence of the new landslides as a validation of our approach. With this multi-temporal data analysis the temporal shift of susceptibility zones could be spatially captured and visualized. Thus, it is possible to add a spatial explicit time element to susceptibility maps in order to improve the assessment of future landslide susceptibility zones.

The pattern of the deviation zones may give information about the dynamic landslide causal factors, that caused the shift of susceptibility zones. The deviation susceptibility map includes the combined effect of temporal environmental change. An increase of maximum 3-day rainfall events was observed (Meusburger and Alewell, 2008). Prolonged rainfall mostly triggers zones with already high susceptibility. Nevertheless, it is necessary to stress that different rainfall amount-duration combinations and difference in rainfall distributions can produce different landslide patterns (Zêzere et al., 2004). To which extend altered snow processes change the susceptibility zones was not evaluated in this study. Geomorphologic feedback mechanism may have effects on landslide susceptibility. On the one hand, susceptibility may decrease over time due to the "emptying" of the slope (Hufschmidt et al., 2005), on the other hand susceptibility may increase over time due to a steepening and undercutting of slopes (Claessens et al., 2007).

The most plausible explanation of a local shift in susceptibility zones is the change in land use types between 1955 and 2006 (Fig. 7). A detailed description of the land use changed that occurred in the valley is given in Meusburger
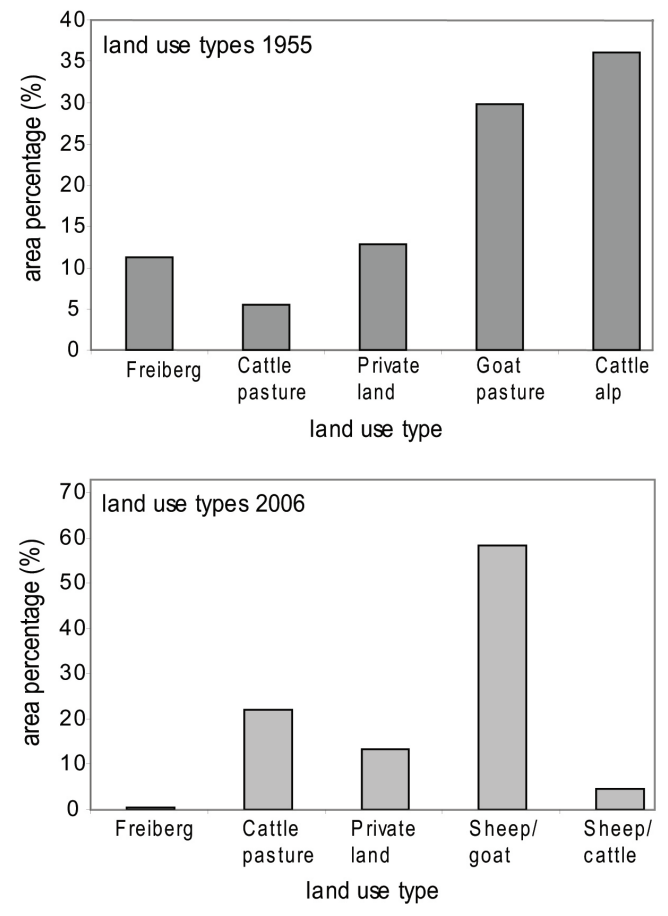

Fig. 7. Difference in area percentage of land use types in 1955 and 2006.

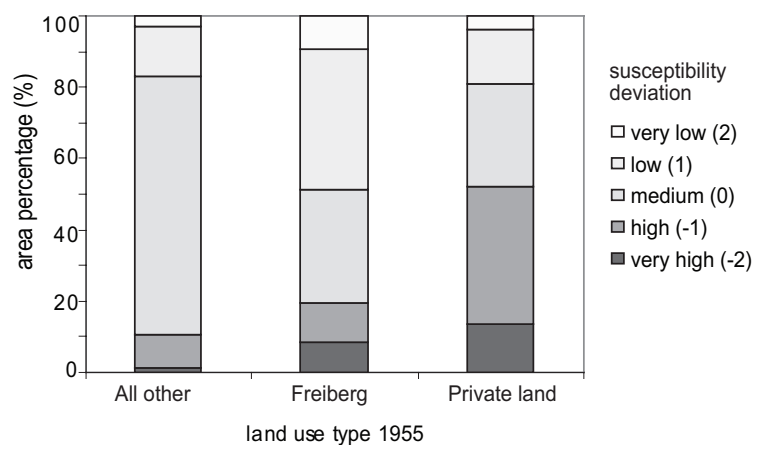

Fig. 8. Frequency distribution of susceptibility deviation zones per land use type. The susceptibility deviation is positive where the susceptibility was one or two zones $(1,2)$ higher in 1959 , negative where the susceptibility was one or two zones $(-1,-2)$ lower in 1959 and zero (0) where no shift of susceptibility occurred.

and Alewell (2008).The percentage of susceptibility deviation zones per land use type of 1955 is given in Fig. 8. The majority of new high susceptibility zones (with a deviation of -2 ) are located within two land use types (Freiberg and Private land). These two land use types were intensified during the last decades. "Freiberg" is a special pasture, which is used only part time of the season. Since the early 70ties, this land use type was replaced by a permanent pasture. This led to severe degradation of the pasture mainly along the lower fence. It is typical for permanent pastures that the pasture intensities are heterogeneously distributed due to the influence of topography and the location of the water sites. Thus, 
in other parts there is also a decrease of susceptibility. The Private land is used as meadow and is nowadays more frequently mown with machines and intensely fertilized with organic manure. Especially the addition of organic fertilizes may be a reason for the enhanced landslide susceptibility, because it favours species with flat rooting (Von Wyl, 1988). For all other land use types, there is no distinct shift of landslide susceptibility zones evident. Generally, land use change seems to be the a plausible dynamic causal factor explaining the spatial shift of landslide susceptibility zones over time.

\section{Conclusions}

Geology, slope and stream-density were the most significant and reliable static parameters for the logistic regression models of 1959 and 2000 and their assessment warrant good potential for spatial landslide susceptibility predictions. Yet, for more recent landslides (since 2000) model prediction was not successful, which confirmed our proposed hypothesis that the predictive capability of statistical susceptibility models may decrease over time. Discrepancies between predicted susceptibility and observed landslides may be due to various dynamic landslide causal factors (e.g. changes in snow and precipitation dynamics, surface cover change). However, the influence of land use changes seemed to be the most likely causal factor in the Urseren Valley. With the proposed new method to analyse multi-temporal data we were able to extract the effect of changing landslide causal factors on the probability of landslides and could improve the prediction for future landslides.

This study implies that the validity of commonly used static landslide susceptibility maps under changing environmental conditions is questionable. Slopes that are predicted as stable can rapidly and mostly unnoticed increase in landslide susceptibility. Thus, a update of the susceptibility maps or a consecutively validation with new landslide data is necessary. Generally, it was shown that it is of decisive impact to understand the dynamic of landslide causal factors in order to guarantee validity of landslide susceptibility maps. The objective of future work would be to develop regional scale models that can include temporal variations of landslide causal factors and, thus, account for changes in landslide susceptibility zones.

Acknowledgements. This study was funded by the Swiss Federal Office for the Environment (Contract-no.: StoBoBio/810. 3129.004/05/0X).

Edited by: A. Guenther

Reviewed by: M. Rossi and two other anonymous referees

\section{References}

Ayalew, L. and Yamagishi, H.: The application of GIS-based logistic regression for landslide susceptibility mapping in the Kakuda-
Yahiko Mountains, Central Japan, Geomorphology, 65, 15 pp., 2005.

Ayalew, L., Yamagishi, H., Marui, H., and Kanno, T.: Landslides in Sado Island of Japan: Part II. GIS-based susceptibility mapping with comparisons of results from two methods and verifications, Eng. Geol., 81, 432-445, 2005.

Backhaus, K.: Multivariate Analysemethoden: Eine anwendungsorientierte Einführung, Springer, Berlin, 11th edn., 830 pp., 2006.

BAFU: Hydrological foundations and data. Real time and historical data: http://www.hydrodaten.admin.ch/d//2087.htm, access: 7 January 2009.

Beven, K. and Kirkby, M.: A physically based, variable contributing area model of basin hydrology, Bulletin of Hydrolic Sciences, 24, 43-69, 1979.

Carrara, A.: Multivariate models for landslide hazard evaluation, J. Int. Ass. Math. Geol., 15, 403-426, 1983.

Carrara, A., Cardinali, M., Detti, R., Guzzetti, F., Pasqui, V., and Reichenbach, P.: GIS techniques and statistical-models in evaluating landslide hazard, Earth Surf. Proc. Land., 16, 427-445, 1991.

Carrara, A., Guzzetti, F., Cardinali, M., and Reichenbach, P.: Current limitations in modeling landslide hazard, Proceedings of IAMG'98, 195-203, 1998.

Carrara, A., Crosta, G., and Frattini, P.: Geomorphological and historical data in assessing landslide hazard, Earth Surf. Proc. Land., 28, 1125-1142, 2003.

Carson, M. A.: The mechanics of erosion, Pion Ltd., London, 174 pp., 1971.

Chung, C. F. and Fabbri, A. G.: Validation of spatial prediction models for landslide hazard mapping, Nat. Hazards, 30, 451472, 2003.

Claessens, L., Schoorl, J. M., and Veldkamp, A.: Modelling the location of shallow landslides and their effects on landscape dynamics in large watersheds: An application for Northern New Zealand, Geomorphology, 87, 16-27, 2007.

Clerici, A., Perego, S., Tellini, C., and Vescovi, P.: A GISbased automated procedure for landslide susceptibility mapping by the Conditional Analysis method: the Baganza valley case study (Italian Northern Apennines), Environ. Geol., 50, 941961, 2006.

Dai, F. C. and Lee, C. F.: Landslide characteristics and slope instability modeling using GIS, Lantau Island, Hong Kong, Geomorphology, 42, 213 pp., 2002.

Davis, J. C., Chung, C. J., and Ohlmacher, G. C.: Two models for evaluating landslide hazards, Comput. Geosci., 32, 1120-1127, 2006.

Ermini, L., Catani, F., and Casagli, N.: Artificial Neural Networks applied to landslide susceptibility assessment, Geomorphology, 66, 327 pp., 2005.

Fabbri, A. G., Chung, C.-J. F., Cendrero, A., and Remondo, J.: Is prediction of future landslides possible with a GIS?, Nat. Hazards, 30, 487-503, 2003.

Fehr, W.: Geologische Karte der Urserenzone, Kommisionsverlag: A. Franke A.G., Bern, 1926.

Frei, C., Calanca, P., Schär, C., Wanner, H., Schaedler, B., Haeberli, W., Appenzeller, C., Neu, U., Thalmann, E., Ritz, C., and Hohmann, R.: Grundlagen. Klimaänderungen und die Schweiz 2050 - Erwartete Auswirkungen auf Umwelt, Gesellschaft und 
Wirtschaft, OcCC Report, 2007.

Gomez, H. and Kavzoglu, T.: Assessment of shallow landslide susceptibility using artificial neural networks in Jabonosa River Basin, Venezuela, Eng. Geol., 78, 11-27, 2005.

Gorsevski, P. V., Gessler, P. E., Boll, J., Elliot, W. J., and Foltz, R. B.: Spatially and temporally distributed modeling of landslide susceptibility, Geomorphology, 80, 178-198, 2006.

Guzzetti, F., Carrara, A., Cardinali, M., and Reichenbach, P.: Landslide hazard evaluation: a review of current techniques and their application in a multi-scale study, Central Italy, Geomorphology, 31, 181 pp., 1999.

Guzzetti, F., Reichenbach, P., Ardizzone, F., Cardinali, M., and Galli, M.: Estimating the quality of landslide susceptibility models, Geomorphology, 81, 166-184, 2006.

Hufschmidt, G., Crozier, M., and Glade, T.: Evolution of natural risk: research framework and perspectives, Nat. Hazards Earth Syst. Sci., 5, 375-387, 2005, http://www.nat-hazards-earth-syst-sci.net/5/375/2005/.

IPCC: Climate Change 2007: The physical science basis. Summary for policymakers, 661 10th session of working group I of the IPCC, Paris, 2007.

Irigaray, C., Fernández, T., El Hamdouni, R., and Chacón, J.: Evaluation and validation of landslide-susceptibility maps obtained by a GIS matrix method: examples from the Betic Cordillera (southern Spain), Nat. Hazards, 41, 61-79, 2007.

Kaegi, H. U.: Die traditionelle Kulturlandschaft im Urserental: Beitrag zur alpinen Kulturgeographie, Ph.D. thesis, University of Zurich, Switzerland, 212 pp., 1973.

Kanungo, D. P., Arora, M. K., Sarkar, S., and Gupta, R. P.: A comparative study of conventional, ANN black box, fuzzy and combined neural and fuzzy weighting procedures for landslide susceptibility zonation in Darjeeling Himalayas, Eng. Geol., 85, 347-366, 2006

Kemper, W. D. and Rosenau, R. C.: Soil cohesion as affected by time and water-content, Soil Sci. Soc. Am. J., 48, 1001-1006, 1984.

Komac, M.: A landslide susceptibility model using the Analytical Hierarchy Process method and multivariate statistics in perialpine Slovenia, Geomorphology, 74, 17 pp., 2006.

Labhart, T. P.: Planbeilage: Geologisch-tektonische Übersichtskarte Aarmassiv, Gotthardmassiv und Tavetscher Zwischenmassiv, Balkema A. A., Rotterdam, 1999.

Meusburger, K. and Alewell, C.: Impacts of anthropogenic and environmental factors on the occurrence of shallow landslides in an alpine catchment (Urseren Valley, Switzerland), Nat. Hazards Earth Syst. Sci., 8, 509-520, 2008, http://www.nat-hazards-earth-syst-sci.net/8/509/2008/

Ohlmacher, G. C. and Davis, J. C.: Using multiple logistic regression and GIS technology to predict landslide hazard in northeast Kansas, USA, Eng. Geol., 69, 331 pp., 2003.

Petley, D., Hearn, G., Hart, A., Rosser, N., Dunning, S., Oven, K., and Mitchell, W.: Trends in landslide occurrence in Nepal, Nat. Hazards, 43, 23-44, 2007.

Pietola, L., Horn, R., and Yli-Halla, M.: Effects of trampling by cattle on the hydraulic and mechanical properties of soil, Soil Till. Res., 82, 99-108, 2005.

Remondo, J., González, A., De Terán, J. R. D., Cendrero, A., Fabbri, A., and Chung, C.-J. F.: Validation of Landslide Susceptibility Maps; Examples and Applications from a Case Study in
Northern Spain, Nat. Hazards, 30, 437-449, 2003.

Rickli, C., Zimmerli, P., and Böll, A.: Effects of vegetation on shallow landslides: an analysis of the events of August 1997 in Sachseln, Switzerland, International Conference on Landslides. Causes, Impacts and Countermeasures, 575-584, 2001.

Russi, A.: Erhebung der Viehzahlen in Urseren, Korperation Urseren: Talkanzlei Urseren, Andermatt, 2006.

Santacana, N., Baeza, B., Corominas, J., De Paz, A., and Marturia, J.: A GIS-based multivariate statistical analysis for shallow landslide susceptibility mapping in La Pobla de Lillet area (Eastern Pyrenees, Spain), Nat. Hazards, 30, 281-295, 2003.

Schauer, T.: Die Blaikenbildung in den Alpen, Schriftreihe Bayerisches Landesamt für Wasserwirtschaft, 1-29, 1975.

Suezen, M. L. and Doyuran, V.: Data driven bivariate landslide susceptibility assessment using geographical information systems: a method and application to Asarsuyu catchment, Turkey, Eng. Geol., 71, 303-321, 2004.

Swisstopo: Reproduziert mit Bewilligung von swisstopo, 2006.

Tasser, E., Mader, M., and Tappeiner, U.: Effects of land use in alpine grasslands on the probability of landslides, Basic Appl. Ecol., 4, 271-280, 2003.

Van Den Eeckhaut, M., Vanwalleghem, T., Poesen, J., Govers, G., Verstraeten, G., and Vandekerckhove, L.: Prediction of landslide susceptibility using rare events logistic regression: A case-study in the Flemish Ardennes (Belgium), Geomorphology, 76, 392 410, 2006

Van Westen, C. J.: The modelling of landslide hazard using GIS, Surv. Geophys., 21, 241-255, 2000.

Van Westen, C. J. and Lulie Getahun, F.: Analyzing the evolution of the Tessina landslide using aerial photographs and digital elevation models, Geomorphology, 54, 77 pp., 2003.

Varnes, D. J.: Landslide hazard zonation: A review of principles and practice, Paris, 63 pp., 1984.

Von Wyl, B.: Düngung an steilen Hängen vergrössert das Risiko von Erdrutschen, Mitteilungen der Naturforschenden Gesellschaft Luzern, 30, 324-335, 1988.

Wills, C. J. and McCrink, T. P.: Comparing landslide inventories: The map depends on the method, Environ. Eng. Geosci., 8, 279293, 2002.

WRB: IUSS Working Group World reference base for soil resources, Food and Agriculture Organization of the Unites Nations, Rom, 128 pp., 2006

Wyss, R.: Die Urseren-Zone - Lithostatigraphie und Tektonik, Eclogae Geol. Helv., 79, 731-767, 1986.

Yesilnacar, E. and Topal, T.: Landslide susceptibility mapping: A comparison of logistic regression and neural networks methods in a medium scale study, Hendek region (Turkey), Eng. Geol., 79, 251 pp., 2005.

Zêzere, J. L., Reis, E., Garcia, R., Oliveira, S., Rodrigues, M. L., Vieira, G., and Ferreira, A. B.: Integration of spatial and temporal data for the definition of different landslide hazard scenarios in the area north of Lisbon (Portugal), Nat. Hazards Earth Syst. Sci., 4, 133-146, 2004, http://www.nat-hazards-earth-syst-sci.net/4/133/2004/.

Zhou, C. H., Lee, C. F., Li, J., and Xu, Z. W.: On the spatial relationship between landslides and causative factors on Lantau Island, Hong Kong, Geomorphology, 43, 197-207, 2002. 